\title{
Impact of cadmium and lead on soil microbial biomass nitrogen of the botanical garden of Ahmadu Bello University, Nigeria
}

\begin{abstract}
This study is aimed at evaluating the effect of heavy metals on soil microbial processes. The effects of Lead $(\mathrm{Pb})$ and Cadmium $(\mathrm{Cd})$ at different concentrations were investigated over a period of eight weeks. Chloride salts of $\mathrm{Pb}$ and $\mathrm{Cd}$ were added singly and in combination to soil samples at room temperature $\left(27^{\circ} \mathrm{C}\right)$ in different polythene bags. Samples were taken from the bags at two weeks interval and measurements were taken of the rate of microbial biomass nitrogen (MBN). The results showed that there was a significant decrease in the microbial biomass for all treated soils from the second week to the sixth week. But there was an observed increase in microbial biomass Nitrogen on the eight week. On the $6^{\text {th }}$ week, $40 \mathrm{mgkg}$ ${ }^{1} \mathrm{Cd}$ gave the most significant decrease $(16 \mu \mathrm{g} / \mathrm{g})$ and $1000 \mathrm{mgkg}^{-1} \mathrm{~Pb}$ gave the least significant decrease $(70 \mu \mathrm{g} / \mathrm{g})$ of MBN.
\end{abstract}

Keywords: accumulation, mineralization, microbial biomass nitrogen, heavy metals
Volume 3 Issue 3 - 2018

\section{Oijagbe IJ,Abubakar BY, Edogbanya PRO}

Department of Biology,Ahmadu Bello University, Nigeria

Correspondence: Oijagbe IJ, Department of Biology, Ahmadu bello University, Zaria, Nigeria, Tel 080364I 58I4,

Email joijagbe@gmail.com

Received: June 12, 2018 | Published: August 09, 2018

\section{Introduction}

Heavy metals are naturally occurring elements that have a high atomic weight and a density at least 5 times greater than that of water. ${ }^{1}$

There are arguments as to which element should be regarded as a heavy metal. Atomic weight is used as the basis of definition by some authors. ${ }^{2}$ Others point to those metals with a specific gravity of greater than 4.0, or greater than 5.0. Most recently, the term "heavy metal" has been used as a general term for those metals and semimetals with potential human or environmental toxicity. ${ }^{1,3}$

Metal distribution between soil and vegetation is a key issue in assessing environmental effect of metals in the environment. ${ }^{3}$

Heavy metal toxicity to plants vary with plant species, specific metal, concentration, chemical form, and soil composition and $\mathrm{pH}$, as many heavy metals are considered to be essential for plant growth and similarly, many heavy metals act as essential trace nutrients of animals and human body. ${ }^{4}$

Some of these heavy metals like $\mathrm{Cu}$ and $\mathrm{Zn}$ serve either as cofactor and activators of enzyme reactions e.g. informing enzymes/substrate metal complex ${ }^{5}$ or show an ability to cause chemical change such as prosthetic group in metalloproteins. ${ }^{6}$ These essential trace metal nutrients take part in redox reactions, electron transfer and structural functions in nucleic acid metabolism. ${ }^{7}$ Some of the metal such as $\mathrm{Cd}$, $\mathrm{Hg}$ and As, etc. are strongly poisonous to metal sensitive enzymes, resulting in growth inhibition and death of organisms. ${ }^{5}$

Most plants depend on soil, but plants and their associated microorganisms also play a vital role in the formation or alteration of soil..$^{8}$

Soil Carbon is predominantly derived from plants, directly or indirectly, and whilst weathering may be due to physical and chemical influences, most weathering processes involve plants, primarily roots, or microbial activities that depend on root-derived Carbon. ${ }^{7,8}$
Some microorganisms in the soil are responsible for nitrogen fixation, assimilation and degradation of organic residues to release nutrients. ${ }^{9,10}$

Heavy metal toxicity has an inhibitory effect on plant growth, enzymatic activity, stoma function, photosynthesis activity and accumulation of other nutrient elements and also damages the root system. To the concern of the soil however, the effects of heavy metals pollutants could be enormous. Major amongst which is their effects on microbial activities. ${ }^{11}$

Restrictions placed on the levels of accumulation of heavy metals in agricultural soils are based on known effects of heavy metals on plant uptake and animal health but takes no account of the effects on soil microorganisms or important microbial processes like carbon and nitrogen mineralization, microbial biomass carbon and nitrogen and respiration. ${ }^{12}$ Hence, there is need to evaluate the effects of these heavy metals at varying concentration on soil microorganisms as it will further provide valid information for determining restrictions limits. Therefore, this study seeks to provide useful and valid information on the possible impacts of Cadmium and Lead on the microbial biomass nitrogen of the soil.

In this work, the effects of Lead $(\mathrm{Pb})$ and Cadmium $(\mathrm{Cd})$ at varied concentrations on soil microbial processes were studied singly and in combination. The microbial biomass and the rates of nitrogen and carbon mineralization were monitored.

\section{Materials and methods}

Soil samples were collected from the Botanical Garden of the Department of Biological Sciences, Ahmadu Bello University, Samaru Main Campus, Zaria (Lat $11^{\circ} 11^{1} \mathrm{~N}$; Long $7^{\circ} 38^{1} \mathrm{~N}$; Altitude $660 \mathrm{~m}$ above sea level). It is about $4188604 \mathrm{~m}^{2}$ (4.2hectares) and segmented into 19 plots. It is a relatively undisturbed site with no farming and grazing activities and located in guinea savannah zone of Nigeria with distinct dry and rainy season. However, for this study, the garden was 
divided into two sections; the area dominated by trees and grasses. All soil samples collected from the sampling points was pooled together to obtain a homogenous unity sample. The soil sample was stored in plastic bags and transported to the Department of Biological Sciences. Soil heavy metal content was analyzed using the Atomic Absorption Spectrophotometer (Shimazu AAS, model AA-6800) at NARICT, Basawa, Zaria (Table 3). Other soil analyses were done at the Institute of Agricultural Research (IAR), Samaru, Zaria. Soil pH was measured in 1:2 soil to water ratio using $\mathrm{pH}$ meter (PHS-3C). Soil organic matter $(\mathrm{OM})$ was determined by wet oxidation methods as described by Walkley and Black (1934) (Table 1). Soil particles analysis (Table 1) was done using hydrometer method as described by Bouyoucos (1951)

Table I Characteristics of the soil

\begin{tabular}{ll}
\hline Parameters & Results \\
\hline $\mathrm{pH}\left(\mathrm{H}_{2} \mathrm{O}\right)$ & 6.1 \\
Organic carbon (\%) & 1.56 \\
Total nitrogen (\%) & 0.195 \\
Soil organic matter (\%) & 2.69 \\
Clay (\%) & 14 \\
Silt (\%) & 49 \\
Sand $(\%)$ & 37 \\
Textural class (U.S.D.A) & LOAM \\
$\mathrm{Pb}(\mathrm{mg} / \mathrm{kg})$ & ND (NOT DETECTED) \\
$\mathrm{Cd}(\mathrm{mg} / \mathrm{kg})$ & $0.00007 \mathrm{I}$ \\
\hline
\end{tabular}

Microbial biomass carbon was determined by the fumigation extraction method 17. Soil samples were sieved using $2 \mathrm{~mm}$ sieve to remove dirt. Sieved soil samples $(1 \mathrm{~kg})$ were distributed into eighteen (18) $25 \mathrm{~cm}$ diameter polythene pots labeled appropriately. Soil samples in the pots were mixed with salts solutions of $\mathrm{Cd}$ as Cadmium Chloride $\mathrm{CdCl}_{2}$ (20mg and $40 \mathrm{mg}$ ), $\mathrm{Pb}$ as Lead Chloride $\mathrm{PbCl}_{2}(1000 \mathrm{mg}$ and $2000 \mathrm{mg}$ ) separately and in combination. The soil sample with no heavy metal amendment was used as control. All the analyses were done in triplicates.

The results were analyzed by two-way analysis of variance (ANOVA) at $95 \%$ confidence interval. Differences between the control and other treatments were assessed using Duncan multiple range test (DMRT).

\section{Results and discussion}

Table 1 shows the characteristics of the soil used. The results show that the soil is slightly acidic with a $\mathrm{pH}$ value of 6.10 and could be texturally classified as loamy soil (USDA,) with 14\% (clay), $49 \%$ (silt) and $37 \%$ (sand). Table 2 shows the patterns of heavy metal amendment (addition) in pre-incubated soil pots, with concentrations of Lead $1000 \mathrm{mgkg}^{-1}(\mathrm{~Pb} 1), 2000 \mathrm{mgkg}^{-1}(\mathrm{~Pb} 2)$, Cadmium $20 \mathrm{mgkg}^{-}$ ${ }^{1}(\mathrm{Cd} 1), 40 \mathrm{mgkg}^{-1}(\mathrm{Cd} 2)$ and a combination of $1000 \mathrm{mgkg}^{-1} \mathrm{~Pb}$ and $20 \mathrm{mgkg}^{-1} \mathrm{Cd}$. While Table 1 also shows the heavy metal profile of the soil prior to amendment as determined by Atomic Absorption Spectrophotometry (AAS), indicating the presence of $\mathrm{Cd}$ at a very low or insignificant level $(0.000071)$ and $\mathrm{Pb}$ to be undetected (absent).

Table 2 Pattern of metal amendment in pre-incubated soil pots

\begin{tabular}{lll}
\hline Sample & Treatment & Concentration $(\mathbf{m g} / \mathbf{k g})$ \\
\hline $\mathrm{CT}$ & $\mathrm{CONTROL}$ & - \\
$\mathrm{LI}$ & $\mathrm{Pbl}$ & 1000 \\
$\mathrm{~L} 2$ & $\mathrm{~Pb} 2$ & 2000 \\
$\mathrm{Cl}$ & $\mathrm{Cdl}$ & 20 \\
$\mathrm{C} 2$ & $\mathrm{Cd} 2$ & 40 \\
$\mathrm{LICl}$ & $\mathrm{PbI}: \mathrm{Cdl}$ & $1000: 20: 00$
\end{tabular}

The measurement of biomass nitrogen (Table 4.6) progressively declined from week 0 to week 6 , but there was an increase at week 8 . It indicated that the values of all treatments were significantly different $\mathrm{P}>0.05$ from the control. The measurement of week 0 showed that $\mathrm{Pb} 1$ had the highest microbial biomass nitrogen $(308.50 \mu \mathrm{g} / \mathrm{g})$ and $\mathrm{Pb} 2$ had the least $(301.0 \mu \mathrm{g} / \mathrm{g})$ value. $\mathrm{Cd} 1 \mathrm{had}$ the highest $(300 \mu \mathrm{g} / \mathrm{g})$ and $\mathrm{Pb} 1: \mathrm{Cd} 1 \mathrm{had}$ the least $(223.83 \mu \mathrm{g} / \mathrm{g})$ value at week 2 . At the $4^{\text {th }} \mathrm{week}$, $\mathrm{Cd} 1$ had the highest $(150 \mu \mathrm{g} / \mathrm{g})$ and $\mathrm{Pb} 2$ had the least $(106 \mu \mathrm{g} / \mathrm{g})$ value. The highest $(70 \mu \mathrm{g} / \mathrm{g})$ and least $(16 \mu \mathrm{g} / \mathrm{g})$ values at week 6 were from $\mathrm{Pb} 1$ and $\mathrm{Cd} 2$ treatments respectively. At the end of the experiment, $\mathrm{Cd} 1$ had the highest $(150 \mu \mathrm{g} / \mathrm{g})$ and $\mathrm{Pb} 2$ had the least $(73 \mu \mathrm{g} / \mathrm{g})$ value. Cd1 gave the highest mean value of $197.70 \mu \mathrm{g} / \mathrm{g}$ and the least mean value $(147.0 \mu \mathrm{g} / \mathrm{g})$ was obtained from $\mathrm{Pb} 2$ across the treatments. While weeks 0 and 6 had the highest and least mean value of $306.17 \mu \mathrm{g} / \mathrm{g}$ and $85.30 \mu \mathrm{g} / \mathrm{g}$ respectively.

Pollution of soil by heavy metals do not only result in adverse effects on various parameters that have to do with plant quality and yield, but also causes changes in the composition and activity of soil microorganisms. ${ }^{14,15}$ Microbial biomass carbon and nitrogen is a standard technique use to determine the effects of heavy metals on soil microorganisms. ${ }^{16}$

There was a general inhibition of microbial biomass nitrogen after application of heavy metals. Both heavy metals cadmium and lead at their various concentrations and combination showed a negative effect on the microbial biomass nitrogen as shown in Table 3 .

There was direct relationship between metal toxicity and incubation period i.e toxicity of the metal as it increases with increased incubation period. It was estimated that heavy metal toxicity to soil biota varies with time, soil type, speciation, ageing, metal source, organisms and environmental factors. ${ }^{17}$ Also, Sardar et al. (2007) investigated that the extent of inhibition increased significantly with increasing level of heavy metals, and varied with the incubation periods.

Also a similar report indicated decrease in soil microbial biomass with the use of $\mathrm{Cd}$ as the pollutant and that this may be as a result of the change in microbial community structure affected by heavy metals. ${ }^{18}$ This observed decrease in microbial biomass carbon and nitrogen may be as a result of death of cells caused by the disruption of essential functions, and changes in population sizes due to change in viability resulting from the exposure to the metal. ${ }^{19}$ This is the reason for the shock experienced by the soil microbes and the consequent sudden decrease in microbial biomass observed on the $2^{\text {nd }}$ and $4^{\text {th }}$ week. 
Table 3 Mean soil biomass nitrogen for different treatments of $\mathrm{Cd}$ and $\mathrm{Pb}$ for eight weeks $(\mu \mathrm{g} / \mathrm{g})$

\begin{tabular}{|c|c|c|c|c|c|c|}
\hline \multirow{2}{*}{ Treatment } & \multicolumn{6}{|c|}{ Soil biomass nitrogen $(\mu g / g)$} \\
\hline & Week 0 & Week 2 & Week 4 & Week 6 & Week 8 & Mean total \\
\hline Control & $310.00 \pm 0.12^{\mathrm{A}, \mathrm{a}}$ & $308.00 \pm 0.05^{\mathrm{A}, \mathrm{b}}$ & $300.6 \pm 0.1^{A, d}$ & $300.1 \pm 0.02^{A, d}$ & $303.00 \pm 0.02^{A, C}$ & $304.34 \pm 34.60^{\mathrm{A}}$ \\
\hline $\mathrm{Pb} \mathrm{I}$ & $30 \mathrm{I} .50 \pm 0.06^{\mathrm{Fa}}$ & $245.03 \pm 0.04^{\mathrm{D}, \mathrm{b}}$ & $180.33 \pm 33.33^{c, c}$ & $70.00 \pm 0.06^{\mathrm{C}, \mathrm{d}}$ & $75.00 \pm 0.05^{\mathrm{D}, \mathrm{c}}$ & $174.37 \pm 27.17^{D}$ \\
\hline $\mathrm{Pb} 2$ & $308.00 \pm 0.06^{\mathrm{B}, \mathrm{a}}$ & $232.00 \pm 0.12^{\mathrm{E}, \mathrm{c}}$ & $106.00 \pm 0.16^{\mathrm{E}, \mathrm{b}}$ & $53.67 \pm 3.39^{\mathrm{B}, \mathrm{d}}$ & $73.00 \pm 0.0 \mathrm{I}^{\mathrm{E}, \mathrm{e}}$ & $154.53 \pm 26.39 \mathrm{~F}$ \\
\hline Cd I & $306.00 \pm 0.06^{\mathrm{D}, \mathrm{a}}$ & $300.00 \pm 0.06^{\mathrm{B}, \mathrm{b}}$ & $210.00 \pm 0.06^{\mathrm{B}, \mathrm{c}}$ & $22.00 \pm 0.12^{\mathrm{E}, \mathrm{e}}$ & $\mid 50.00 \pm 0.0 I^{B, d}$ & $197.70 \pm 28.18^{B}$ \\
\hline $\mathrm{Cd} 2$ & $307.00 \pm 0.06^{\mathrm{C}, \mathrm{a}}$ & $275.00 \pm 0.1 I^{c, b}$ & $200.00 \pm 0.1 I^{\mathrm{BC}, \mathrm{c}}$ & $16.00 \pm 0.06 \mathrm{~F}^{\mathrm{e}}$ & $78.00 \pm 0.0 I^{D, f}$ & $175.20 \pm 29.93^{c}$ \\
\hline $\mathrm{Pb}: \mathrm{Cd}$ & $304.00 \pm 0.06^{\mathrm{E}, \mathrm{a}}$ & $223.00 \pm 0.00^{\mathrm{F}, \mathrm{b}}$ & $165.00 \pm 0.10^{\mathrm{D}, \mathrm{c}}$ & $50.00 \pm 0.06^{\mathrm{D}, \mathrm{e}}$ & $83.00 \pm 0.02^{c, d}$ & $165.00 \pm 29.23^{E}$ \\
\hline Overall & $306.17 \pm 0.67^{a}$ & $263.83 \pm 26.22^{b}$ & $193.65 \pm\left. 36.9\right|^{b}$ & $85.63 \pm 5.78^{d}$ & $127.66 \pm 7.90^{c}$ & $158.47 \pm 1.12$ \\
\hline
\end{tabular}

Mean \pm S.E; $n=3$; Values with the same UPPERCASED superscript down a column (except overall) are not significantly different (P>0.05); Values with the same lowercased superscript across a row (except overall) are not significantly different difference $(P>0.05)$.

There is also a suggestion of additional energy cost to soil microbes as the reason for reduced soil microbial biomass under heavy metals stress conditions, and such additional cost can result in a decrease in the amount of substrate that is available for growth. ${ }^{20}$ And this is supported by the suggestion made by Liao that soil microbes under stress divert energy from growth to cell maintenance functions and may therefore be a possible explanation for the decrease in biomass in the contaminated soils. ${ }^{21}$ In this study, a decrease in microbial biomass was observed from the beginning to the $6^{\text {th }}$ week of the incubation with $\mathrm{Pb}$ and $\mathrm{Cd}$ treated soils which may be due to decline in the size of soil microbial community and a reduction of carbon and nitrogen mineralization in these soils. ${ }^{22}$ The direct negative effect of these heavy metals on soil microbial biomass is the main reason for significant increase in the nitrogen in this study.

The later rise in microbial biomass on the $8^{\text {th }}$ week may be as a result of development of tolerance and shifts in community structure to compensate for lost of more sensitive populations..$^{23,24} \mathrm{He}$ explained that such tolerant population tend to show high level of growth due to increase in viability resulting from the shift in microbial community structure. Heavy metals strongly reduced the numbers and species diversity of the soil microbial communities but, enhanced the development of metal-resistant microbial population. ${ }^{25}$ Previous studies indicated that heavy metals could cause severe phytotoxic effects, and might act as a driving force for the evolution of tolerant populations. ${ }^{26-30}$

\section{Conclusion}

Heavy metal $(40 \mathrm{mg} / \mathrm{kg} \mathrm{Cd})$ causes significant decrease in microbial biomass nitrogen (from $307.00 \pm 0.06$ to $16.00 \pm 0.06 \mu \mathrm{g} / \mathrm{g}$ ).

\section{Acknowledgements}

The authors acknowledge the financial support of Mr Emmanuel Oijagbe, the technical support of the staff of Biological Science department of Ahmadu Bello University, Zaria and Mr Jatau Bawa (a staff at the Institute for Agricultural Research, ABU, Zaria) for his technical support.

\section{Conflict of interest}

The author declares no conflict of interest.

\section{References}

1. Tchounwou PB, Yedjou CG, Patlolla AK, et al. Heavy metals toxicity and the environment. EXS. 2012;101:133-164.

2. Hussain CM, Kharisov B. Advanced environmental analysis: applications of nanomaterials (Vol. 1). Royal Society of Chemistry. 2016.

3. Saunders JE, Jastrzembski BG, Buckey JC, et al. Hearing loss and heavy metal toxicity in a nicaraguan mining community: audiological results and case reports. Audiol Neurootol. 2013;18(2):101-113.

4. Abolude FO, Adesoji H. Characterization of heavy metal pollution around processing factory using Atomic Absorption Spectrophotometer. Research J Appli Sci. 2006;1(1-4):16-18.

5. WHO. Evaluation of certain food additives contaminants. Sixty-first report of the joint FAO/WHO Expert Committee on Food Additives. WHO Technical Report Series, No. Geneva: WHO922; 2014. 176 p.

6. Singh A, Prasad SM, Singh RP. Plant Responses to Xenobiotics. Switzerland: Springer; 2016.

7. Rao NS, Shivashankara KS, Laxman RH. Abiotic stress physiology of horticultural crops. Switzerland: Springer; 2016.

8. Pate JS, Verboom WH. Contemporary biogenic formation of clay pavements by eucalypts: further support for the phytotarium concept. Ann Bot. 2009;103(5):673-685.

9. Mildvan AS. 9 Metals in Enzyme Catalsis. Enzymes. 1970;2:445-536.

10. Pate JS, Verboom WH. Contemporary biogenic formation of clay pavements by eucalypts: further support for the phytotarium concept. Ann Bot. 2009;103(5):673-685

11. Raven JA, Edwards D. Roots: evolutionary origins and biogeochemical significance. Journal of Experimental Botany. 2001;52(suppl_1):381-401.

12. Beerling DJ, Berner RA. Feedbacks and the coevolution of plants and atmospheric $\mathrm{CO}_{2}$. Proc Natl Acad Sci USA. 2005;102(5):1302-1305.

13. Brookes PC. The use of microbiological parameters in monitoring soil pollution by heavy metals. Biology and Fertility of Soils. 1995;19(4):269279

14. Nwuche CO, Ugoji EO. Effects of heavy metal pollution on the soilmicrobial activity. Int J Environ Sci Tech. 2008;5(3):409-414.

15. Wyszkowska J, Wyszkowski M. Effect of cadmium and magnesium on microbiological activity in soil. Pol J Environ Stud. 2002;11(5):585-591. 
16. Ghorbani NR, Salehrastin N, Moeini A. Heavy metals affect the microbial populations and their activities. Proc 17th World Congr Soil Sci. 2002;2234:1-11.

17. Vance ED, Brookes PC, Jenkinson DS. An extraction method for measuring soil microbial biomass. Soil Biology and Biochemistry. 1987;19(6):703-707.

18. Giller KE, Witter E, Mcgrath SP. Toxicity of heavy metals to microorganisms and microbial processes in agricultural soils: A review. Soil Biol Biochem. 1998;30(10-11):1389-1414.

19. Akmal M, Jianming X. Microbial biomass and bacterial community changes by $\mathrm{Pb}$ contamination in acidic soil. J Agric Biol Sci. 2009;1(1):30-37.

20. Chander K, Ulrich E, Jörgensen RG, et al. Decomposition of 14C labelled wheat straw in repeatedly fumigated and non-fumigated soils with different levels of heavy metal contamination. Biol Fert Soils. 2002;35(2):8691.

21. Vig K, Megharaj M, Sethunathan N, et al. Bioavailability and toxicity of cadmium to microorganisms and their activities in soil: a review. $A d v E n$ viron Res. 2003;8:121-135.

22. Verma RK, Singh CP, Suman A, et al. Effect of heavy metals on soil respiration during decomposition of sugarcane (Saccharum officinarum L.) trash in different soils. Plant Soil Environment. 2010;56(2):76-81.

23. Waldrop MP, Balser TC, Firestone MK. Linking microbial community composition to function in a tropical soil. Soil Biol Biochem. 2000;32:1837-1846.
24. Cervantes C. Copper resistance mechanism in bacteria and fungi. FEMS microbial Rev. 1994;14(2):121-137.

25. Liao M, Chen CL, Zeng LS, et al. Influence of lead acetate on soil microbial biomass and community structure in two different soils with the growth of Chinese cabbage (Brassica chinensis). Chemosphere. 2007;66(7):1197-1205.

26. Setälä $H$, McLean M. Decomposition rate of organic substrates in relation to the species diversity of soil saprophytic fungi. Oecologia. 2004;139:98107

27. Frossard R. Contaminant uptake by plants. In: Soil Monitoring. Basel: Birkhäuser Verlag. 1993. p. 7-24.

28. Frostegard A, Baath E. The use of phospholipids fatty acid analysis to estimate bacterial and fungal biomass in soil. Biol Fertil Soils. 1996;22(12):59-65.

29. Yao H, Xu J, Huang C. Substrate utilization pattern, biomass and activity of microbial communities in a sequence of heavy metal-polluted paddy soils. Geoderma. 2003;115:139-148.

30. Shu WS, Ye ZH, Lan CY, et al. Lead, zinc and copper accumulation and tolerance in populations of Paspalum distichum and Cynodon dactylon. Environ Pollut. 2002;120(2):445-453. 